\title{
Using Electronic Medical Record Data for Research in a Healthcare Information and Management Systems Society (HIMSS) Analytics Electronic Medical Record Adoption Model (EMRAM) Stage 7 Hospital in Beijing: Cross-sectional Study
}

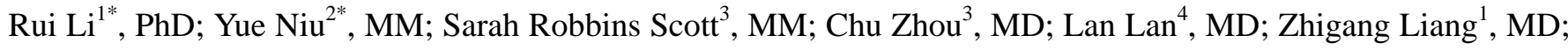
$\mathrm{Jia} \mathrm{Li}^{1}, \mathrm{MD}$

${ }^{1}$ Information Center, Xuanwu Hospital, Capital Medical University, Beijing, China

${ }^{2}$ Statistical Procedure Department, Blueballon (Beijing) Medical Research Co, Ltd, Beijing, China

${ }^{3}$ National Center for AIDS/STD Control and Prevention, Chinese Center for Disease Control and Prevention, Beijing, China

${ }^{4}$ West China Biomedical Big Data Center, West China Hospital, Sichuan University, Beijing, China

* these authors contributed equally

Corresponding Author:

Jia Li, MD

Information Center

Xuanwu Hospital

Capital Medical University

45 Changchun Street

Beijing, 100053

China

Phone: 861083929211

Email: lij@xwhosp.org

\section{Abstract}

Background: With the proliferation of electronic medical record (EMR) systems, there is an increasing interest in utilizing EMR data for medical research; yet, there is no quantitative research on EMR data utilization for medical research purposes in China.

Objective: This study aimed to understand how and to what extent EMR data are utilized for medical research purposes in a Healthcare Information and Management Systems Society (HIMSS) Analytics Electronic Medical Record Adoption Model (EMRAM) Stage 7 hospital in Beijing, China. Obstacles and issues in the utilization of EMR data were also explored to provide a foundation for the improved utilization of such data.

Methods: For this descriptive cross-sectional study, cluster sampling from Xuanwu Hospital, one of two Stage 7 hospitals in Beijing, was conducted from 2016 to 2019. The utilization of EMR data was described as the number of requests, the proportion of requesters, and the frequency of requests per capita. Comparisons by year, professional title, and age were conducted by double-sided chi-square tests.

Results: From 2016 to 2019, EMR data utilization was poor, as the proportion of requesters was 5.8\% and the frequency was 0.1 times per person per year. The frequency per capita gradually slowed and older senior-level staff more frequently used EMR data compared with younger staff.

Conclusions: The value of using EMR data for research purposes is not well studied in China. More research is needed to quantify to what extent EMR data are utilized across all hospitals in Beijing and how these systems can enhance future studies. The results of this study also suggest that young doctors may be less exposed or have less reason to access such research methods.

(JMIR Med Inform 2021;9(8):e24405) doi: 10.2196/24405

\section{KEYWORDS}

electronic medical records; data utilization; medical research; China 


\section{Introduction}

Electronic medical records (EMRs), or digitized versions of patient medical charts, are often considered a key component of a hospital or health care system's health information system [1]. EMR systems have transformed data and record keeping in the medical field, and they enable providers to more systematically track patient information over time, promote a more holistic approach to patient care, support the streamlining of preventative screening, support the monitoring of patients, and improve overall quality [2,3]. For these reasons, there has been rapid growth in the implementation of EMR systems in health care settings throughout the world in recent decades [4-9]. Subsequently, the amount and availability of clinical data automatically collected by EMRs are increasing at an exponential rate [10,11], and EMRs have been recognized as a valuable resource for observational data and for large-scale analyses [12,13]. As such, EMR data are often used for research purposes in many universities and organizations around the world [14,15]. Using EMR data for medical research [16,17] has several benefits, such as being low cost, having a large volume of data, and saving time because there is no need to recruit and retain participants [18-21]. Thus, it is believed that using EMRs to obtain clinical information has the potential to revolutionize medical research in the coming years [22,23].

In China, the EMR system has become the core system for the collection and management of hospital information, as the National Electronic Medical Record System has been promoted across the country since 2011 [24-26]. Furthermore, with many hospitals implementing the Healthcare Information and Management Systems Society (HIMSS) Analytics Electronic Medical Record Adoption Model (EMRAM) standards, numerous Chinese hospitals have become international standard and accredited hospitals [27]. One result of this shift has been that increasing numbers of western institutions are collaborating with China on medical research using EMR data [28].

As research using EMR data has become increasingly prevalent, researchers have been pondering how to better explore the technical value of EMR data. In addition, there exists a growing body of literature on the feasibility and efficacy of using electronic health records for research purposes. Electronic health records (EHRs) are inclusive of a broader view of patient care, including diagnoses, medications, immunizations, family medical history, and provider contact information. EMR data, however, are digital versions of patient charts. They contain notes and information collected by and for clinicians in that particular care setting and are mostly used by providers for diagnosis and treatment [3]. In China and abroad, studies on the topic of using EMR or EHR data for research have primarily focused on the challenges of using such systems. Researchers over a decade ago raised concerns regarding the quality and comprehensiveness of clinical data being collected in EMR systems and mentioned that there were systematic biases inherent to data collected primarily for clinical care [29]. Other studies have identified other barriers, including legal, technical, ethical, social, and resource-related issues, such as privacy protection, data security, data custodians, and the motives for collecting data, as well as a lack of incentives to share data
$[15,30]$. An additional systematic review identified four domains of potential limitations, including data quality issues (91.7\%), data preprocessing challenges $(53.3 \%)$, privacy concerns (18.3\%), and potential for limited generalizability (21.7\%) [31]. Some studies have consequently developed a list of caveats and recommendations for overcoming such limitations [30,32-35].

Additionally, the majority of existing research focuses on the quality of EMR/EHR data and its related challenges [36-39]. These challenges can be divided into five primary areas as follows: completeness, consistency, validity, reliability, and accuracy [40-42]. Some analyses have aimed to develop assessment frameworks to ensure data quality across studies [43], but there are few studies that quantitatively explore how and to what extent EMR or EHR data are being collected and used in China. Thus, it is necessary to build EMR data quality metrics and standardize routine documentation to enable its secondary use for medical research [44-46].

The paralleled use of EMR data for medical research has been noted. In one such study, the characteristics of EMR data in China were compared against data collected in hospitals in the United States in order to understand system and cultural differences that may exist between Chinese and English clinical documents [47]. A study by van Velthoven et al [48], for example, shed light on the feasibility of extracting EMR data across a number of countries. These studies are useful for understanding how data collection systems in China and the use of EMR data for medical research may adapt to more international standards, further supporting collaboration between Chinese and foreign research institutions.

Currently, in Chinese hospitals, the data available to researchers are limited in scope to just EMRs, rather than full EHRs. In order to further promote utilizing EMR data for research, a quantitative investigation of the current status of data utilization is warranted, since understanding the status quo is a prerequisite for determining barriers and improving the existing system. It is necessary to explore the obstacles that hinder EMR data utilization for medical research from the perspective of data consumers, but there is currently no quantitative research or surveys published on the recent status of EMR data utilization for medical research in any institution or region in China. Thus, this study aimed to understand the landscape, including barriers and obstacles, of utilizing EMR data for medical research in Chinese medical institutions. This study will provide data managers and medical research managers with a broader understanding of what types of data are being used; what extent they are being utilized; and who is accessing such data, laying the groundwork for further promotion of this research method.

\section{Methods}

\section{Study Design}

A serial, cross-sectional, descriptive study was carried out at Xuanwu Hospital, Capital Medical University (XWHCMU) in Beijing, China. XWHCMU is a large 1600-bed tertiary general hospital with a complete EMR data repository and is one of the two HIMSS Analytics EMRAM Stage 7 hospitals in Beijing. The HIMSS Analytics EMRAM incorporates methodology and 
algorithms to automatically score hospitals around the world relative to their EMR capabilities. A Stage 7 rating signifies the highest level of EMR function and application, achieving a near paperless environment that harnesses technology to support optimized patient care. At Xuanwu Hospital, the EMRAM data system was implemented in 2014. All employees receive training on the content and scope of the EMR data available, the permissions for EMR data utilization, and the process of requesting and obtaining EMR data.

\section{Data Sources and Extraction}

All data from the Office Information System (Office Automation) was extracted, because each EMR data extraction request in the hospital must be approved through the EMR data management module in the Office Automation. Variables of interest included data request purpose, requester ID, requester department, and data request time. If the purpose of the data request was for scientific research, it was included in the study. The requester ID was used to retrieve the age and professional title of all requesters in the hospital human resources dictionary. The requester ID was also used as the main index for data matching and integration, forming a total of 933 EMR data request records for scientific research purposes between 2016 and 2019.

The use of EMR data for research purposes by key departments in the hospital was also assessed. XWHCMU evaluates the scientific research performance of each department every year based on a set of 18 evaluation criteria, including published papers/books, transformation of scientific research results, academic events, and approved scientific research projects. The top 10 clinical departments with the highest cumulative research work performance score over the last 4 years were selected as "key departments" for this study. The performance score of each department, evaluation indicators, and standards of scientific research work can be found in Multimedia Appendix 1.

\section{Statistical Analysis}

The data were analyzed using IBM SPSS Statistics for Windows version 23.0 (IBM Corp). The data were expressed using times, frequencies, and percentages. The chi-square test was used for categorical variables, with $P<.05$ considered statistically significant. A summary of the statistical indicators, their definitions, and how they were calculated can be found in Table 1 .

Table 1. Summary of the statistical indicators of the study, their corresponding definitions, and how they were calculated.

\begin{tabular}{lll}
\hline Statistical indicators & Definition & Calculation \\
\hline Times & An absolute value index & $\begin{array}{l}\text { The cumulative value of the number of requests for electronic medical } \\
\text { record (EMR) data for research by professional and technical personnel } \\
\text { in the observation unit (institution or department) during the observation } \\
\text { period. }\end{array}$
\end{tabular}

Frequency An intensity index

Proportion of requesters

A ratio indicator

Number of departments that did not request data

Absolute increment of frequency

Cumulative growth

Annual growth

Frequency growth rate

Relative ratio with fixed base

Link relative
A counting indicator

The absolute value of growth

The absolute value of growth

The absolute value of growth

The growth rate of frequency

The growth rate of frequency

The growth rate of frequency

The number of requests/ $\sum$ the number of professional and technical personnel in this observation unit $\times$ time.

$\sum$ the number of professional and technical personnel who have requested EMR data for research $/ \sum$ the number of professional and technical personnel in this observation unit.

The number of departments that never requested EMR data for scientific research during the observation period.

Can be further divided into cumulative growth and annual growth.

The difference between the frequency of a certain year and that at baseline (2016).

The difference between the frequency of a year and that of the previous year.

Divided into fixed base ratio growth rate and link ratio growth rate.

The net increase rate of frequency in a certain year compared with the baseline (2016), that is, the ratio of a certain year's frequency to the baseline frequency minus $100 \%$.

The net increase rate of frequency in a year compared with the frequency of the previous year, that is, the ratio of frequency of a year to that of the previous year minus $100 \%$.

\section{Results}

\section{EMR Data Utilization From 2016 to 2019 at XWHCMU}

The frequency of EMR data utilization increased from 0.06 times per person per year (2016) to 0.1 times per person per

year (2019), and the proportion of requesters increased from $3.3 \%$ (2016) to $5.8 \%$ (2019), as seen in Table 2. The majority of medical departments at the hospital are using the EMR system, with the number not using the system decreasing from 21 (2016) to 5 (2019). The fixed base ratio growth rate of the frequency of EMR data utilization was $66.67 \%$, and the year-to-year growth rate in 2019 was zero. 
The frequency at which EMR data was used for medical research increased significantly between 2016 and 2018 (Table 2). The growth rate frequency has gradually slowed down over the past
4 years, with a bottleneck occurring in 2019, during which the growth rate was $0 \%$.

Table 2. General trends in the utilization of electronic medical records in Xuanwu Hospital, Capital Medical University, Beijing, China between 2016 and 2019.

\begin{tabular}{|c|c|c|c|c|c|c|c|c|}
\hline \multirow[t]{2}{*}{ Year } & \multirow[t]{2}{*}{ Times } & \multirow[t]{2}{*}{ Frequency } & \multirow[t]{2}{*}{$\begin{array}{l}\text { Proportion of requesters, } \\
\mathrm{n} / \mathrm{N}(\%)\end{array}$} & \multirow[t]{2}{*}{$\begin{array}{l}\text { Number of departments that } \\
\text { did not request data, n/N (\%) }\end{array}$} & \multicolumn{2}{|c|}{$\begin{array}{l}\text { Absolute increment of } \\
\text { request frequency }\end{array}$} & \multicolumn{2}{|c|}{$\begin{array}{l}\text { Request frequency growth rate, } \\
\%\end{array}$} \\
\hline & & & & & $\begin{array}{l}\text { Cumulative } \\
\text { growth }\end{array}$ & $\begin{array}{l}\text { Annual } \\
\text { growth }\end{array}$ & $\begin{array}{l}\text { Relative ratio } \\
\text { with fixed base }\end{array}$ & Link relative \\
\hline 2016 & 171 & 0.06 & $98 / 3060(3.2 \%)$ & $21 / 47(44.7 \%)$ & $\mathrm{N} / \mathrm{A}^{\mathrm{a}}$ & N/A & N/A & N/A \\
\hline 2017 & 201 & 0.07 & $119 / 2935(4.1 \%)$ & $19 / 47(40.4 \%)$ & 0.01 & 0.01 & 16.67 & 16.67 \\
\hline 2018 & 288 & 0.10 & $153 / 2883(5.3 \%)$ & $14 / 47(29.8 \%)$ & 0.04 & 0.03 & 66.67 & 42.86 \\
\hline 2019 & 273 & 0.10 & $163 / 2667(6.1 \%)$ & $5 / 47(10.6 \%)$ & 0.04 & 0.00 & 66.67 & 0.00 \\
\hline
\end{tabular}

${ }^{\mathrm{a}}$ N/A: not applicable.

\section{Utilization of EMR Data by Key Departments at XWHCMU From 2016 to 2019}

hospital (Table 3). The proportion of data utilization by key departments decreased from $70.0 \%$ in 2016 to $49.4 \%$ in 2019.

The key departments had a per capita request frequency lower than the average per capita request frequency for the overall 
Table 3. Utilization of electronic medical record data in the key scientific research departments of Xuanwu Hospital, Capital Medical University, Beijing, China between 2016 and 2019.

\begin{tabular}{|c|c|c|c|c|c|c|c|c|c|c|c|c|c|}
\hline \multirow{2}{*}{$\begin{array}{l}\text { Research } \\
\text { score } \\
\text { ranking }\end{array}$} & \multirow{2}{*}{$\begin{array}{l}\text { Depart- } \\
\text { ment }\end{array}$} & \multicolumn{3}{|l|}{2016} & \multicolumn{3}{|l|}{2017} & \multicolumn{3}{|l|}{2018} & \multicolumn{3}{|l|}{2019} \\
\hline & & Times & $\begin{array}{l}\text { Proportion } \\
\text { of the } \\
\text { whole hos- } \\
\text { pital re- } \\
\text { quest } \\
\text { times, \% }\end{array}$ & $\begin{array}{l}\text { Frequen- } \\
\text { cy }\end{array}$ & Times & $\begin{array}{l}\text { Proportion } \\
\text { of the } \\
\text { whole hos- } \\
\text { pital re- } \\
\text { quest } \\
\text { times, \% }\end{array}$ & $\begin{array}{l}\text { Frequen- } \\
\text { cy }\end{array}$ & Times & $\begin{array}{l}\text { Proportion } \\
\text { of the } \\
\text { whole hos- } \\
\text { pital re- } \\
\text { quest } \\
\text { times, \% }\end{array}$ & $\begin{array}{l}\text { Frequen- } \\
\text { cy }\end{array}$ & Times & $\begin{array}{l}\text { Proportion } \\
\text { of the } \\
\text { whole hos- } \\
\text { pital re- } \\
\text { quest } \\
\text { times, \% }\end{array}$ & $\begin{array}{l}\text { Frequen- } \\
\text { cy }\end{array}$ \\
\hline 1 & $\begin{array}{l}\text { Neurolo- } \\
\text { gy }\end{array}$ & 49 & $28.8 \%$ & 0.16 & 57 & $28.4 \%$ & 0.19 & 70 & $24.3 \%$ & 0.23 & 65 & $23.8 \%$ & 0.16 \\
\hline 2 & $\begin{array}{l}\text { Neuro- } \\
\text { surgery }\end{array}$ & 18 & $10.6 \%$ & 0.08 & 17 & $8.5 \%$ & 0.08 & 16 & $5.6 \%$ & $0.07^{\mathrm{a}}$ & 8 & $2.9 \%$ & $0.03^{\mathrm{a}}$ \\
\hline 3 & $\begin{array}{l}\text { Radiolo- } \\
\text { gy }\end{array}$ & 7 & $4.1 \%$ & 0.06 & 6 & $3.0 \%$ & $0.05^{\mathrm{a}}$ & 8 & $2.8 \%$ & $0.07^{\mathrm{a}}$ & 7 & $2.6 \%$ & $0.06^{\mathrm{a}}$ \\
\hline 4 & $\begin{array}{l}\text { General } \\
\text { Surgery }\end{array}$ & 5 & $2.9 \%$ & $0.05^{\mathrm{a}}$ & 21 & $10.4 \%$ & 0.20 & 16 & $5.6 \%$ & 0.15 & 10 & $3.7 \%$ & $0.07^{\mathrm{a}}$ \\
\hline 5 & $\begin{array}{l}\text { Function- } \\
\text { al Neuro- } \\
\text { surgery }\end{array}$ & 1 & $0.6 \%$ & $0.01^{\mathrm{a}}$ & 1 & $0.5 \%$ & $0.01^{\mathrm{a}}$ & 4 & $1.4 \%$ & $0.05^{\mathrm{a}}$ & 4 & $1.5 \%$ & $0.05^{\mathrm{a}}$ \\
\hline 6 & $\begin{array}{l}\text { Interven- } \\
\text { tional Ra- } \\
\text { diogra- } \\
\text { phy }\end{array}$ & 0 & $0 \%$ & $0.00^{\mathrm{a}}$ & 1 & $0.5 \%$ & $0.03^{\mathrm{a}}$ & 9 & $3.1 \%$ & 0.26 & 5 & $1.9 \%$ & 0.14 \\
\hline 7 & $\begin{array}{l}\text { Vascular } \\
\text { Surgery }\end{array}$ & 13 & $7.7 \%$ & 0.19 & 15 & $7.5 \%$ & 0.22 & 13 & $4.5 \%$ & 0.19 & 5 & $1.9 \%$ & $0.07^{\mathrm{a}}$ \\
\hline 8 & $\begin{array}{l}\text { Anesthesi- } \\
\text { ology }\end{array}$ & 0 & $0 \%$ & $0.00^{\mathrm{a}}$ & 2 & $1.0 \%$ & $0.01^{\mathrm{a}}$ & 2 & $0.7 \%$ & $0.01^{\mathrm{a}}$ & 6 & $2.0 \%$ & $0.03^{\mathrm{a}}$ \\
\hline 9 & Pharmacy & 25 & $14.7 \%$ & 0.20 & 19 & $9.5 \%$ & 0.15 & 33 & $11.5 \%$ & 0.26 & 22 & $8.1 \%$ & 0.17 \\
\hline 10 & $\begin{array}{l}\text { Orthope- } \\
\text { dics }\end{array}$ & 1 & $0.6 \%$ & $0.02^{\mathrm{a}}$ & 3 & $1.5 \%$ & $0.05^{\mathrm{a}}$ & 3 & $1.0 \%$ & $0.05^{\mathrm{a}}$ & 3 & $1.0 \%$ & $0.05^{\mathrm{a}}$ \\
\hline Total & $\mathrm{N} / \mathrm{A}^{\mathrm{b}}$ & 119 & $70.0 \%$ & N/A & 142 & $70.8 \%$ & N/A & 174 & $60.5 \%$ & N/A & 135 & $49.4 \%$ & N/A \\
\hline $\begin{array}{l}\text { Frequen- } \\
\text { cy of the } \\
\text { overall } \\
\text { hospital }\end{array}$ & N/A & N/A & N/A & 0.06 & N/A & N/A & 0.07 & N/A & N/A & 0.10 & N/A & N/A & 0.10 \\
\hline
\end{tabular}

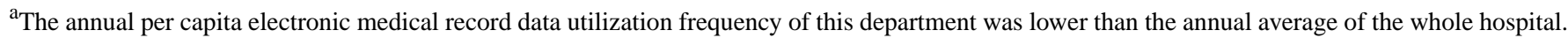
The annual average is based on all departments.

${ }^{\mathrm{b}} \mathrm{N} / \mathrm{A}$ : not applicable.

\section{Utilization of EMR Data by Age}

As seen in Figure 1, the trend in the proportion of individuals using EMR data varied between 2016 and 2019. Those aged 36 to 45 years made up the largest proportion of researchers using
EMR data from 2016 to 2018, though this trend declined in 2019 , when those aged 46 years of age or older made up the larger proportion of requests. Generally speaking, those under the age of 35 years represented the smallest proportion of EMR data users at the hospital. 
Figure 1. Trend in the proportion of electronic medical record data users by age group at Xuanwu Hospital, Capital Medical University, Beijing, China between 2016 and 2019 .

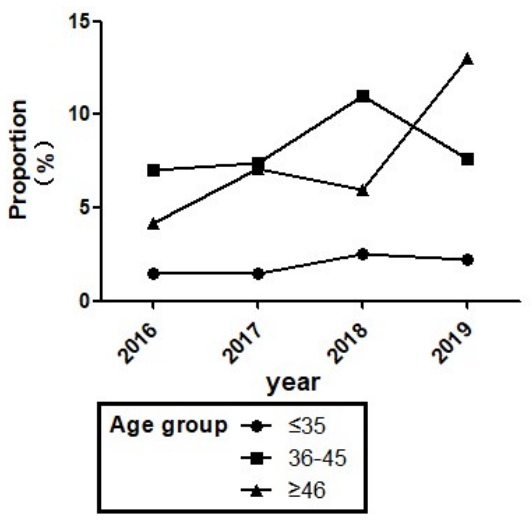

\section{Utilization of EMR Data by Staff Level}

In 2016, the proportion of junior-level professionals using EMR data for medical research was the lowest (1.2\%), while those with senior-level titles made up the largest proportion of EMR data users $(8.8 \%)$. This trend continued through 2019, as seen in Table 4. Between 2016 and 2019, senior-level professionals made up the largest proportion of those requesting EMR data $(255 / 533,47.8 \%)$, followed by intermediate-level staff (161/533, $30.2 \%)$ and then junior-level staff $(117 / 533,21.9 \%)$. Over the 4-year period, the proportion of senior- and intermediate-level staff requesting EMR data increased, while there was no significant change in the junior-level staff group.

Table 4. Electronic medical record data utilization by junior-, intermediate-, and senior-level staff at Xuanwu Hospital, Capital Medical University, Beijing, China between 2016 and 2019.

\begin{tabular}{|c|c|c|c|c|c|c|}
\hline \multirow[t]{2}{*}{ Year } & \multicolumn{3}{|l|}{ Professional title } & \multirow[t]{2}{*}{ Total, $\mathrm{n} / \mathrm{N}(\%)$} & \multirow[t]{2}{*}{ Chi-square $(d f)$} & \multirow[t]{2}{*}{$P$ value } \\
\hline & $\begin{array}{l}\text { Junior-level requester, } \mathrm{n} / \mathrm{N} \\
(\%)\end{array}$ & $\begin{array}{l}\text { Intermediate-level requester, } \\
\mathrm{n} / \mathrm{N}(\%)\end{array}$ & $\begin{array}{l}\text { Senior-level requester, } \mathrm{n} / \mathrm{N} \\
(\%)\end{array}$ & & & \\
\hline 2016 & $23 / 1894(1.2 \%)$ & $26 / 658(4.0 \%)$ & $49 / 508(9.6 \%)$ & $\begin{array}{l}98 / 3060 \\
(3.2 \%)\end{array}$ & $84.155(5)$ & $<.001$ \\
\hline 2017 & $22 / 1811(1.2 \%)$ & $37 / 648(5.7 \%)$ & $60 / 476(12.6 \%)$ & $\begin{array}{l}119 / 2935 \\
(4.1 \%)\end{array}$ & $131.622(5)$ & $<.001$ \\
\hline 2018 & $38 / 1772(2.1 \%)$ & $44 / 644(6.8 \%)$ & $71 / 467(15.2 \%)$ & $\begin{array}{l}153 / 2883 \\
(5.3 \%)\end{array}$ & $191.04(5)$ & $<.001$ \\
\hline 2019 & $34 / 1755(1.9 \%)$ & $54 / 497(10.9 \%)$ & $75 / 415(18.1 \%)$ & $\begin{array}{l}163 / 2667 \\
(6.1 \%)\end{array}$ & $147.299(5)$ & $<.001$ \\
\hline
\end{tabular}

\section{Discussion}

\section{Principal Findings}

This study aimed to understand the landscape of EMR data utilization for medical research at XWHCMU between 2016 and 2019. In the past 4 years, the use of EMR data for medical research was quite uncommon at the hospital. Though overall utilization rates increased each year, the overall growth rate is slowing, with a frequency of just 0.1 times per person per year in 2019. More so, key research departments at the hospital are not utilizing EMR data for research purposes, while junior-level staff continue to be limited in their ability to use the system.

According to the results of this study, the proportion of hospital staff using EMR data was less than $6 \%$ and the frequency of EMR data utilization did not exceed 10 times per 100 researchers in 1 year. Meanwhile, even the top 10 research departments at Xuanwu Hospital reduced the frequency at which they used EMR data for medical research purposes. Current clinical scientific research data collection still heavily relies on semimanual input. In China, the Hospital Information System has continuously improved, with the EMR system accumulating a large amount of valuable health care data. According to the Annual Report on the Status of Chinese Hospital Informatization (2018-2019), more than one-fourth of tertiary medical institutions have invested in EMR data utilization for research [26]. Since prospective clinical research is more demanding and difficult to perform, retrospective research is an important means of obtaining clinical evidence. EMR data can be not only used as independent data, but also tied to administrative data for retrospective research $[13,16,17]$, saving both time and money for medical institutions wishing to carry out such research studies with limited resources $[18,19]$. Thus, steps within the hospital should be taken to promote the awareness of this type of available research data, along with the encouragement to carry our medical research using these systems. Further evaluations are needed to gain a better understanding as to why current medical staff may not be accessing such data or why these trends may be declining.

Although the frequency of data usage has increased significantly (the fixed base ratio growth rate was $66.67 \%$ ), this was not found to be significant, and a bottleneck was noted in 2019. 
The reasons for this decline in data utilization over the last 3 years were not analyzed, though further follow-up studies to determine the factors influencing the decisions for EMR data utilization would be beneficial. These studies could examine if the external environment has changed, including policies for utilizing EMR data, mechanisms for data sharing, and procedures for requesting and obtaining data.

This study also found that older more senior professionals at Xuanwu Hospital were more likely to use EMR data compared to younger age groups $(P<.001)$. Junior-level staff should be the main force for tapping the value of the EMR data, as they need scientific research achievements to be promoted and younger individuals tend to accept new technologies and new methods faster compared to older populations [49]. In large general hospitals in China, all professional and technical staff are required to have independent scientific research capabilities and publications. However, there is a serious contrast between actual need and actual use of EMR data among junior-level staff, as seen in this study. While this study did not evaluate such contrasts, other research has aimed to identify why such barriers to data access may exist, as noted in the Introduction section of this manuscript. The first issue of data access may be inequality, as bureaucracy has been noted as one of main barriers when using EMR data for research [48]. If this is the case at hospitals in Beijing, it is urgent to establish an equal and open EMR data utilization mechanism. Another potential barrier is whether there is a lack of awareness of the research value of EMR data among younger junior-level staff [50]. Lastly, the EMR data utilization skills of junior-level staff may be insufficient $[51,52]$. If awareness and skills are indeed lacking, it is required to establish systematic training and technical support services for this group [53,54].

\section{Limitations}

As this study was limited to one hospital in Beijing, China, the results cannot represent the general situation of other medical institutions in China. In addition, due to information confidentiality, more personnel-related information could not be obtained and the included indicators may not be comprehensive. For other factors that may affect the utilization of EMR data, further research is needed.

\section{Conclusions}

This is the first quantitative study considering EMR data utilization for medical research in a hospital in Beijing. It offers unique insights into the frequency of EMR data usage for medical research purposes and who is utilizing such data. The value of using EMR data for research purposes remains understudied. The results of this study also suggest that young doctors may be less exposed or have less reason to access such research methods. More research is needed to quantify to what extent EMR data are utilized across all hospitals in Beijing and how these systems can enhance future studies.

\section{Acknowledgments}

We are grateful to the Information Center, the Scientific Research Management Department, and the Human Resources Department for their cooperation throughout the study. The Information Center helped us extract the data request records; the Scientific Research Management Department provided the performance score of each department, evaluation indicators, and standards of scientific research work; and the Human Resources Department provided related personnel information. We thank Anjie Ren for guidance on this study.

\section{Conflicts of Interest}

None declared.

\section{Multimedia Appendix 1}

Research performance assessment standard of XuanWu hospital. [DOC File , 104 KB-Multimedia Appendix 1]

\section{References}

1. Lugn NE. Connecting for Health: Global Vision, Local Insight. J Telemed Telecare 2016 Jun 22;12(3):161-162. [doi: $\underline{10.1258 / 135763306776738585]}$

2. Rhee C, Dantes R, Epstein L, Murphy DJ, Seymour CW, Iwashyna TJ, CDC Prevention Epicenter Program. Incidence and Trends of Sepsis in US Hospitals Using Clinical vs Claims Data, 2009-2014. JAMA 2017 Oct 03;318(13):1241-1249 [FREE Full text] [doi: 10.1001/jama.2017.13836] [Medline: 28903154]

3. What are the differences between electronic medical records, electronic health records, and personal health records? Health Information Technology. URL: https://www.healthit.gov/faq/ what-are-differences-between-electronic-medical-records-electronic-health-records-and-personal [accessed 2020-01-01]

4. Kawaguchi H, Koike S, Ohe K. Facility and Regional Factors Associated With the New Adoption of Electronic Medical Records in Japan: Nationwide Longitudinal Observational Study. JMIR Med Inform 2019 Jun 14;7(2):e14026 [FREE Full text] [doi: 10.2196/14026] [Medline: $\underline{\text { 31199307] }}$

5. O'Donnell A, Kaner E, Shaw C, Haighton C. Primary care physicians' attitudes to the adoption of electronic medical records: a systematic review and evidence synthesis using the clinical adoption framework. BMC Med Inform Decis Mak 2018 Nov 13;18(1):101 [FREE Full text] [doi: 10.1186/s12911-018-0703-x] [Medline: $\underline{\text { 30424758] }}$ 
6. Owens B. Family doctors call for guaranteed access to EMR data for research and quality improvement. CMAJ 2018 Jan 15;190(2):E60-E61 [FREE Full text] [doi: 10.1503/cmaj.109-5543] [Medline: 29335269]

7. Zhang XY, Zhang P. Recent perspectives of electronic medical record systems. Exp Ther Med 2016 Jun;11(6):2083-2085 [FREE Full text] [doi: 10.3892/etm.2016.3233] [Medline: 27284289]

8. Henry J. Adoption of Electronic Health Record Systems among U.S. Non-federal Acute Care Hospitals: 2008-2013. Health Information Technology. 2014. URL: https://www.healthit.gov/sites/default/files/briefs/oncdatabrief16.pdf [accessed 2020-02-01]

9. Ministry of Health and Welfare. URL: http://www.mohw.go.kr/eng/ [accessed 2020-02-05]

10. Puskarich MA, Callaway C, Silbergleit R, Pines JM, Obermeyer Z, Wright DW, et al. Priorities to Overcome Barriers Impacting Data Science Application in Emergency Care Research. Acad Emerg Med 2019 Jan;26(1):97-105 [FREE Full text] [doi: 10.1111/acem.13520] [Medline: 30019795]

11. Ehrenstein V, Nielsen H, Pedersen AB, Johnsen SP, Pedersen L. Clinical epidemiology in the era of big data: new opportunities, familiar challenges. Clin Epidemiol 2017;9:245-250 [FREE Full text] [doi: 10.2147/CLEP.S129779] [Medline: 28490904]

12. Sun W, Cai Z, Li Y, Liu F, Fang S, Wang G. Data Processing and Text Mining Technologies on Electronic Medical Records: A Review. J Healthc Eng 2018;2018:4302425 [FREE Full text] [doi: 10.1155/2018/4302425] [Medline: 29849998]

13. Dean BB, Lam J, Natoli JL, Butler Q, Aguilar D, Nordyke RJ. Review: use of electronic medical records for health outcomes research: a literature review. Med Care Res Rev 2009 Dec;66(6):611-638. [doi: 10.1177/1077558709332440] [Medline: 19279318]

14. De Moor G, Sundgren M, Kalra D, Schmidt A, Dugas M, Claerhout B, et al. Using electronic health records for clinical research: the case of the EHR4CR project. J Biomed Inform 2015 Feb;53:162-173 [FREE Full text] [doi: 10.1016/j.jbi.2014.10.006] [Medline: 25463966]

15. Canaway R, Boyle DI, Manski-Nankervis JAE, Bell J, Hocking JS, Clarke K, et al. Gathering data for decisions: best practice use of primary care electronic records for research. Med J Aust 2019 Apr;210 Suppl 6:S12-S16 [FREE Full text] [doi: 10.5694/mja2.50026] [Medline: 30927466]

16. Linn G, Ying Y, Chang K. Does Computerized Physician Order Entry Benefit from Dynamic Structured Data Entry? A Quasi-Experimental Study. BMC Med Inform Decis Mak 2018 Nov 26;18(1):109 [FREE Full text] [doi: 10.1186/s12911-018-0709-4] [Medline: 30477491]

17. Reimer AP, Milinovich A, Madigan EA. Data quality assessment framework to assess electronic medical record data for use in research. Int J Med Inform 2016 Jun;90:40-47 [FREE Full text] [doi: 10.1016/j.ijmedinf.2016.03.006] [Medline: 27103196]

18. Safran C, Bloomrosen M, Hammond WE, Labkoff S, Markel-Fox S, Tang PC, Expert Panel. Toward a national framework for the secondary use of health data: an American Medical Informatics Association White Paper. J Am Med Inform Assoc 2007;14(1):1-9 [FREE Full text] [doi: 10.1197/jamia.M2273] [Medline: 17077452]

19. Weiskopf N, Rusanov A, Weng C. Sick patients have more data: the non-random completeness of electronic health records. AMIA Annu Symp Proc 2013;2013:1472-1477 [FREE Full text] [Medline: 24551421]

20. Lingren T, Sadhasivam S, Zhang X, Marsolo K. Electronic medical records as a replacement for prospective research data collection in postoperative pain and opioid response studies. Int J Med Inform 2018 Mar;111:45-50 [FREE Full text] [doi: 10.1016/j.ijmedinf.2017.12.014] [Medline: 29425633]

21. Lai YS, Afseth JD. A review of the impact of utilising electronic medical records for clinical research recruitment. Clin Trials 2019 Apr;16(2):194-203. [doi: 10.1177/1740774519829709] [Medline: 30764659]

22. Duz M, Marshall JF, Parkin T. Validation of an Improved Computer-Assisted Technique for Mining Free-Text Electronic Medical Records. JMIR Med Inform 2017 Jun 29;5(2):e17 [FREE Full text] [doi: 10.2196/medinform.7123] [Medline: 28663163]

23. Murdoch TB, Detsky AS. The inevitable application of big data to health care. JAMA 2013 Apr 03;309(13):1351-1352. [doi: 10.1001/jama.2013.393] [Medline: 23549579]

24. 2008-2013 white paper on the status of hospital informatization in China. Chima. URL: https://chima.org.cn/Sites/Uploaded/ File/2020/07/216373092256678657801360117.pdf [accessed 2020-03-05]

25. 2017-2018 white paper on the status of hospital informatization in China. Chima. URL: https://chima.org.cn/Html/News/ Articles/11000170.html [accessed 2020-02-05]

26. 2018-2019 white paper on the status of hospital informatization in China. Chima. URL: https://chima.org.cn/Html/News/ Articles/4878.html [accessed 2020-03-05]

27. Stage 6 and 7 Achievement. HIMSS Analytics. URL: https://www.himssanalytics.org/asia-pacific/stage-6-7-achievement [accessed 2020-04-01]

28. Wu Y, Lei J, Wei WQ, Tang B, Denny JC, Rosenbloom ST, et al. Analyzing differences between chinese and english clinical text: a cross-institution comparison of discharge summaries in two languages. Stud Health Technol Inform 2013;192:662-666 [FREE Full text] [Medline: 23920639] 
29. Weiner MG, Embi PJ. Toward reuse of clinical data for research and quality improvement: the end of the beginning? Ann Intern Med 2009 Sep 01;151(5):359-360 [FREE Full text] [doi: 10.7326/0003-4819-151-5-200909010-00141] [Medline: 19638404]

30. Cowie MR, Blomster JI, Curtis LH, Duclaux S, Ford I, Fritz F, et al. Electronic health records to facilitate clinical research. Clin Res Cardiol 2017 Jan;106(1):1-9 [FREE Full text] [doi: 10.1007/s00392-016-1025-6] [Medline: 27557678]

31. Edmondson M, Reimer A. Challenges Frequently Encountered in the Secondary Use of Electronic Medical Record Data for Research. Comput Inform Nurs 2020 Jul;38(7):338-348. [doi: 10.1097/CIN.0000000000000609] [Medline: 32149742]

32. Hersh WR, Weiner MG, Embi PJ, Logan JR, Payne PRO, Bernstam EV, et al. Caveats for the use of operational electronic health record data in comparative effectiveness research. Med Care 2013 Aug;51(8 Suppl 3):S30-S37 [FREE Full text] [doi: 10.1097/MLR.0b013e31829b1dbd] [Medline: 23774517]

33. Hersh W, Cimino J, Payne PR, Embi P, Logan J, Weiner M, et al. Recommendations for the use of operational electronic health record data in comparative effectiveness research. EGEMS (Wash DC) 2013;1(1):1018 [FREE Full text] [doi: 10.13063/2327-9214.1018] [Medline: 25848563]

34. Callahan A, Shah NH, Chen JH. Research and Reporting Considerations for Observational Studies Using Electronic Health Record Data. Ann Intern Med 2020 Jun 02;172(11 Suppl):S79-S84 [FREE Full text] [doi: 10.7326/M19-0873] [Medline: 32479175]

35. Milinovich A, Kattan MW. Extracting and utilizing electronic health data from Epic for research. Ann Transl Med 2018 Feb;6(3):42 [FREE Full text] [doi: 10.21037/atm.2018.01.13] [Medline: 29610734]

36. Ni K, Chu H, Zeng L, Li N, Zhao Y. Barriers and facilitators to data quality of electronic health records used for clinical research in China: a qualitative study. BMJ Open 2019 Jul 02;9(7):e029314 [FREE Full text] [doi: 10.1136/bmjopen-2019-029314] [Medline: 31270120]

37. Jensen PB, Jensen LJ, Brunak S. Mining electronic health records: towards better research applications and clinical care. Nat Rev Genet 2012 May 02;13(6):395-405. [doi: 10.1038/nrg3208] [Medline: 22549152]

38. Raman SR, Curtis LH, Temple R, Andersson T, Ezekowitz J, Ford I, et al. Leveraging electronic health records for clinical research. Am Heart J 2018 Aug;202:13-19. [doi: 10.1016/j.ahj.2018.04.015] [Medline: 29802975]

39. Ming-Yu Z. Resource Management of Big Data of Clinical Research. China Digital Medicine 2020;15(08). [doi: 10.3969/j.issn.1673-7571.2020.08.034]

40. Long JA, Richards JA, Seko CE. The Canadian Institute for Health Information (CIHI) Data Quality Framework, Version 1: A Meta-Evaluation and Future Directions. In: Proceedings of the 6th International Conference on Information Quality. 2001 Presented at: 6th International Conference on Information Quality; 2001; Cambridge, MA p. 370-383 URL: https:/ /Www.zhangqiaokeyan.com/academic-conference-foreign_proceedings-of-the-6th-internatial-cfere thesis/020512600211. $\underline{\mathrm{html}}$

41. Opmeer BC. Electronic Health Records as Sources of Research Data. JAMA 2016 Jan 12;315(2):201-202. [doi: 10.1001/jama.2015.15419] [Medline: 26757473]

42. Baier AW, Snyder DJ, Leahy IC, Patak LS, Brustowicz RM. A Shared Opportunity for Improving Electronic Medical Record Data. Anesth Analg 2017 Sep;125(3):952-957. [doi: 10.1213/ANE.0000000000002134] [Medline: 28632540]

43. Weiskopf NG, Weng C. Methods and dimensions of electronic health record data quality assessment: enabling reuse for clinical research. J Am Med Inform Assoc 2013 Jan 01;20(1):144-151 [FREE Full text] [doi: 10.1136/amiajnl-2011-000681] [Medline: 22733976]

44. Brown ML. Can't you just pull the data? The limitations of using of the electronic medical record for research. Paediatr Anaesth 2016 Nov;26(11):1034-1035. [doi: 10.1111/pan.12951] [Medline: 27747978]

45. von Martial S, Brix TJ, Klotz L, Neuhaus P, Berger K, Warnke C, et al. EMR-integrated minimal core dataset for routine health care and multiple research settings: A case study for neuroinflammatory demyelinating diseases. PLoS One 2019;14(10):e0223886 [FREE Full text] [doi: 10.1371/journal.pone.0223886] [Medline: 31613917]

46. Assessing Data Quality for Healthcare Systems Data Used in Clinical Research. NIH Collaboratory. 2014. URL: https:/ /dcricollab.dcri.duke.edu/sites/NIHKR/KR/Assessing-data-quality_V1\%200.pdf [accessed 2020-04-05]

47. Wu Y, Lei J, Wei W, Tang B, Denny JC, Rosenbloom ST, et al. Analyzing differences between chinese and english clinical text: a cross-institution comparison of discharge summaries in two languages. Stud Health Technol Inform 2013;192:662-666 [FREE Full text] [Medline: 23920639]

48. van Velthoven MH, Mastellos N, Majeed A, O'Donoghue J, Car J. Feasibility of extracting data from electronic medical records for research: an international comparative study. BMC Med Inform Decis Mak 2016 Jul 13;16:90 [FREE Full text] [doi: 10.1186/s12911-016-0332-1] [Medline: 27411943]

49. Lee CC, Czaja SJ, Moxley JH, Sharit J, Boot WR, Charness N, et al. Attitudes Toward Computers Across Adulthood From 1994 to 2013. Gerontologist 2019 Jan 09;59(1):22-33 [FREE Full text] [doi: 10.1093/geront/gny081] [Medline: 29982458]

50. Zhao JW. Establishment of a clinical research big data center in a hospital in Henan province. Chin J Hosp Admin 2020;36(8):668-671. [doi: 10.3760/cma.j.cn111325-20200415-01110]

51. Haixing W. Discussion on the application of health big data in clinical research. Chinese Hospitals 2020;24(7):63-64. [doi: 10.19660/j.issn.1671-0592.2020.07.19] 
52. Rui L, Lan L, Zhigang L, Zhifang G, Yan Y, Jia L. Analysis of Data Utilization of Hospital Information System for Clinical Research. Chinese Journal of Health Informatics and Management 2018;15(1):86-89. [doi: 10.3969/j.issn.1672-5166.2018.01.017]

53. Fanxiu H. Hospital Big Data Framework System Construction and Data Utilization. Chinese Journal of Health Informatics and Management 2020;17(3):275-278.

54. Jia QG. Practice of cultivating the ability of big data mining in graduates working for professional degree in medical oncology. Chin J Med Edu 2020;19(5):551-554. [doi: 10.3760/cma.j.cn116021-20191204-00125]

\section{Abbreviations}

EHR: electronic health record

EMR: electronic medical record

EMRAM: Electronic Medical Record Adoption Model

HIMSS: Healthcare Information and Management Systems Society

XWHCMU: Xuanwu Hospital, Capital Medical University

Edited by C Lovis; submitted 17.09.20; peer-reviewed by A Reimer, I Mircheva, Z Ren, N Kaur; comments to author 07.10.20; revised version received 01.12.20; accepted 07.06.21; published 03.08.21

Please cite as:

Li R, Niu Y, Scott SR, Zhou C, Lan L, Liang Z, Li J

Using Electronic Medical Record Data for Research in a Healthcare Information and Management Systems Society (HIMSS) Analytics Electronic Medical Record Adoption Model (EMRAM) Stage 7 Hospital in Beijing: Cross-sectional Study

JMIR Med Inform 2021;9(8):e24405

URL: https://medinform.jmir.org/2021/8/e24405

doi: $10.2196 / 24405$

PMID:

CRui Li, Yue Niu, Sarah Robbins Scott, Chu Zhou, Lan Lan, Zhigang Liang, Jia Li. Originally published in JMIR Medical Informatics (https://medinform.jmir.org), 03.08.2021. This is an open-access article distributed under the terms of the Creative Commons Attribution License (https://creativecommons.org/licenses/by/4.0/), which permits unrestricted use, distribution, and reproduction in any medium, provided the original work, first published in JMIR Medical Informatics, is properly cited. The complete bibliographic information, a link to the original publication on https://medinform.jmir.org/, as well as this copyright and license information must be included. 